Federal Reserve Bank of Minneapolis

Research Department Staff Report 344

Revised May 2005

\title{
Were U.S. State Banknotes Priced as Securities?*
}

\author{
Warren E. Weber ${ }^{\dagger}$
}

\begin{abstract}
This study examines the pricing of U.S. state banknotes before 1860 using discount data from New York, Philadelphia, Cincinnati, and Cleveland. The study determines whether these banknotes were priced consistent with their expected net redemption value as securities are. The evidence is mixed. Prices for a bank's notes were higher when the bank was redeeming its notes for specie than when it was not, and banknote prices generally reflected the costs of note redemption. However, the relationship between prices and redemption costs was not tight, and there were cases in which the notes of distant banks went at par.
\end{abstract}

*I am indebted to participants at seminars at the Federal Reserve Bank of Minneapolis, the Federal Reserve Bank of Chicago, the Central Bank Institute of the Federal Reserve Bank of Cleveland, the University of Indiana, the University of Kentucky, Northwestern University, the Ohio State University, the University of Texas, and the University of Western Ontario for helpful comments on an earlier version of this paper. The views expressed herein are those of the author and not necessarily those of the Federal Reserve Bank of Minneapolis or the Federal Reserve System.

${ }^{\dagger}$ Research Department, Federal Reserve Bank of Minneapolis, Box 291, Minneapolis, MN 55480-0291, 612204-5485, 612-204-5515 (fax), wew@minneapolisfed.org 
When it won independence from Great Britain in 1783, the United States had only one bank, the Bank of North America in Philadelphia. This did not remain true for long, however. The number of banks grew rapidly. In 1840 the country had over 700 banks, and in 1860, just before the start of the Civil War, the country had more than 1,350 banks. $^{1}$

Virtually all of these banks issued banknotes - dollar-denominated promises to pay specie to the bearer on demand - that were distinguishable by the issuing bank. ${ }^{2}$ Banknotes circulated hand to hand and were the largest component of currency in circulation during the period. Consequently, large numbers of distinct currencies were in circulation in the country throughout the antebellum period, and, as is known from contemporary sources, these notes circulated at exchange rates that fluctuated over time. ${ }^{3}$

The existence of a large number of currencies circulating at floating exchange rates led some contemporary observers to conclude that these banking arrangements should be changed. For example, the following excerpt from the London Times was used by Senator John Sherman of Ohio in a speech on February 10, 1863, advocating passage of the National Currency Act:

\footnotetext{
${ }^{1}$ These bank counts are based on the series I recently constructed. The series are described in Weber (2005) and can be found at my Web site, http://www.minneapolisfed.org/research/economists/wewproj.html.

${ }^{2}$ During this period, a dollar was defined as a governmentally minted coin containing 371.25 grains of silver. Large denomination coins were made of gold. The gold content of the dollar was changed in 1834 and 1837.

Banknotes were almost always at least $\$ 1$ in denomination, and in many cases banks were restricted to issue notes no smaller than $\$ 5$. Wholesale prices during this time period give these denominations some perspective. In Philadelphia in 1850 flour was between $\$ 0.02$ and $\$ 0.03$ per pound, coffee between $\$ 0.08$ and $\$ 0.13$ per pound, and rye whisky between $\$ 0.22$ and $\$ 0.28$ per gallon (Cole, 1938, pp. 314-15). Overall, consumer prices were roughly 23 times higher in 2002 than they were in 1850 (see the "Composite Consumer Price Index [1860]" in McCusker [1992]).

${ }^{3}$ Specialized publications at the time listed the rates of discount or premium on the notes of banks throughout the country in terms of notes of banks of some city, usually the location of the publication. These "Bank Note Reporters and Counterfeit Detectors" - they also usually contained lists of known counterfeits - were published by or in collaboration with a banknote broker in the particular city. For an excellent discussion of banknote reporters and counterfeit detectors see Dillistin (1949). In addition, many newspapers published tables containing similar information on banknote prices.
} 
By the want of a paper currency that would be taken in every State of the Union at its nominal value the Americans have suffered severely. The different States were, as to their bank notes, so many foreign countries, each refusing the paper of the others, except at continually varying rates of discount.... Through [a national currency] the people will ... gain that deliverance from the previous confusion of their currency which to Europeans appeared a barbarism. (Krooss, 1969, pp. $1361-62)$

In other words, the replacement of notes issued by state banks with a uniform currency would be a welfare improvement. ${ }^{4}$

Notes issued by state banks, however, gave the bearer the option to exchange them for gold or silver, which was valued in and of itself. As Wallace (2003, p. 256) points out, if state banknotes are considered to be "payable-to-the-bearer securities [because of this redemption option], then we might be ... reluctant to accept the conclusion that they should trade at par" and, as a consequence, to question the presumption that a uniform banknote currency that replaced state banknotes was necessarily a welfare improvement. ${ }^{5}$

My purpose here is to determine the extent to which the behavior of the prices of banknotes during the antebellum period is consistent with the view that the public treated them as bearer securities (pure debt claims). Under the assumption of risk neutrality, the price of a security should equal the expected discounted value of its payment stream. For banknotes, the expected payment stream was the expected amount of specie for which the notes could be redeemed net of the cost of redeeming notes at the issuing bank. Thus, given

\footnotetext{
${ }^{4}$ By a uniform currency, I mean that units of distinct currencies with the same numerical designation always trade at par with each other and buy the same quantity of goods at a given location at a given time. Theoretical support for a uniform currency can be found in models like that of Matsuyama, Kiyotaki, and Matsui (1993) and Ravikumar and Wallace (2001). In such models, currencies are fiat (intrinsically useless) objects used to overcome transactions frictions. Nonuniformity of currencies is undesirable because it limits the potential trades that can occur.

${ }^{5}$ National banknotes, which were essentially a uniform currency, came into existence with the passage of the National Currency Act (later called the National Banking Act) in 1863. State banknotes continued to circulate until the passage of a 10 percent tax on them, levied in 1866, effectively drove them out of circulation.
} 
that it took only a short time to redeem notes, their prices should have been equal to their expected net redemption value if they were priced as securities.

This proposition has at least two implications that can be taken to the data. One comes from the fact that although banks generally redeemed their notes in specie on demand, at times many banks suspended specie payments. Such suspensions of payment presumably lowered expectations about the amount of specie for which the notes could be redeemed. If banknotes were treated as securities, then their prices should have fallen when banks issuing them suspended payments. A second testable implication is that redemption costs should have affected banknote prices. If banknotes were treated as securities, then banknotes that had higher redemption costs should have had lower prices.

I find some evidence consistent with the view that banknotes were considered to be securities. First, banknote prices generally responded to changes in expectations concerning the amount of specie for which they could be redeemed, as the proposition predicts. During times when banks had temporarily suspended specie payments, the prices of their notes were lower than when they were redeeming their notes in specie on demand. Second, banknote prices were negatively related to redemption costs, as measured by the cost of traveling to the issuing bank from the location of the banknote price quote.

However, I also find evidence not consistent with the proposition. First, the relationship between banknote prices and travel costs was not tight. Sometimes the discounts on notes of banks from different locations were the same even though the cost of travel to these locations varied greatly, and sometimes the discounts on the notes of banks in different locations varied greatly even though the travel cost to these locations was the same. Second, there are several episodes in which the notes of banks at some distance from the quote lo- 
cation, implying nonzero redemption costs for the notes, were nonetheless quoted at par in that location.

The behavior of state banknote prices during this period has previously been studied by Gorton (1999). His paper, like this one, takes seriously the fact that banknotes could be redeemed for specie at the option of the bearer, and his note-pricing equation is very similar to the one derived here. Further, the empirical results here support Gorton's findings that note prices were lower when banks suspended specie payments and that discounts were not closely related to the issuing bank's distance from the location where the price of its notes was being quoted.

The two studies have three differences, however. The first is that the note-pricing equation derived here takes into account that the quoted prices are in terms of the notes of banks in the location where the price is being quoted, not in terms of goods as in his model. This has important implications for how note prices should behave during bank suspensions. The second is that this study uses price quotes from several locations; his study uses quotes only from Philadelphia. The third is that in this study, banks are considered to be in the same location if they are in the same city. Gorton assumes that they are in the same location if they are in the same state. The reason for my choice is that discounts generally were more uniform across banks in the same city than they were across banks in the same state.

I proceed as follows. The next section presents an explicit formulation of the proposition that if banknotes were treated as securities, their prices should have equaled their expected net redemption value. Section 2 compares banknote prices in periods when specie payments were suspended with prices in periods when banks were redeeming notes for specie. I show that prices changed during bank suspensions, as would be predicted if banknotes were 
treated as securities. Section 3 examines the relationship between banknote prices and redemption costs. I show that although banknote prices and redemption costs were generally negatively related, as should be the case if banknotes were treated as securities, the relationship was not tight and did not vary systematically with changes in costs. I also show that there were costs when the notes of banks located at a considerable distance from the quote location circulated at par in that location. Section 4 concludes. The data on banknote prices used in this study are described in the Appendix.

\section{Banknotes as securities}

To obtain the pricing equation for banknotes if they were viewed as securities, consider the maximization problem of a note broker who buys notes strictly in order to redeem them for gold at the issuing bank. Assume that this note broker is located at $j$, and let $p_{t}(i, j)$ be the price at time $t$ of the notes of a bank at location $i$, as quoted in location $j$ for notes issued by a bank in $j .{ }^{6}$ The price is in local (location $j$ ) banknotes because that is how banknote prices were quoted during this period.

After buying the notes of the bank in $i$, the broker would have shipped them back to the issuing bank and received $q_{t^{\prime}}(i)$ dollars of gold for each dollar of notes presented for redemption. (The time subscript is $t^{\prime}$ to take into account that it may have taken time to get the note back to location $i$ and that what mattered was the redemption rate when the note was presented in the future, not the redemption rate when the broker bought the note.) If the bank at $i$ was redeeming its notes in gold (the bank was not suspended) at $t^{\prime}$, then

\footnotetext{
${ }^{6}$ I use a bank's location as if it were also the bank's designation to simplify notation. Thus, location should be thought of as a street address. If location is thought of as a larger geographical area-a city, for example - then the notation should have both a bank identifier and a location identifier.
} 
$q_{t^{\prime}}(i)=1$. If it was suspended, then $q_{t^{\prime}}(i) \leq 1 .^{7}$ The broker then would have brought the gold back to location $j$ and exchanged it for local banknotes at the rate of $1 / q_{t^{\prime \prime}}(j)$ notes per dollar of gold. (The time subscript here is $t^{\prime \prime}$ to account for the fact that what mattered was the local redemption rate when the broker got the gold back home.)

Under the assumptions that the broker wanted to maximize the discounted expected utility of consumption and that the price of consumption in local banknotes was constant, then the first-order conditions for the broker's problem yield the following Euler equation for the price of the notes of the bank at $i$ :

$$
p_{t}(i, j)=\beta^{t^{\prime \prime}-t} E_{t}\left[\frac{q_{t^{\prime}}(i) u^{\prime}\left(t^{\prime \prime}\right)}{q_{t^{\prime \prime}}(j) u^{\prime}(t)}\right]
$$

where $E_{t}$ is the expectation operator conditional on information at $t, \beta$ is the discount factor, and $u^{\prime}(t)$ is the marginal utility of consumption at time $t .^{8}$

Note redemption also may have involved costs, such as getting the notes back to the issuing bank and returning with specie, that the broker also would have had to pay. Let $\delta_{t}(i, j)$ be the cost of redeeming notes of banks in location $i$. To simplify future exposition, I assume that the time it took to redeem notes at $i$ and bring the gold back to location $j$, $t^{\prime \prime}-t$, was short, so that $u^{\prime}\left(t^{\prime \prime}\right) \approx u^{\prime}(t)$ and $\beta^{t^{\prime \prime}-t} \approx 1$. Thus, I rewrite the Euler equation (1) as

$$
p_{t}(i, j)=g\left\{E_{t}\left[\frac{q_{t^{\prime}}(i)}{q_{t^{\prime \prime}}(j)}\right], \delta_{t}(i, j)\right\},
$$

where $g_{1}>0, g_{2}<0$. This pricing equation is similar to that obtained by Gorton (1999), the

\footnotetext{
${ }^{7} \mathrm{I}$ do not assume that $q_{t^{\prime}}(i)=0$ if the bank at $i$ was suspended because there may have been individuals in location $i$ that would have been willing to give specie for the notes of the bank. An interesting question that will not be answered here is how $q_{t^{\prime}}(i)$ was determined when banks were suspended.

${ }^{8}$ To be strictly correct, the $=$ in $(1)$ should be $\geq$, with equality holding if the broker purchases a positive quantity of notes.
} 
major difference being that the redemption rate for local notes also appears in the formulation. This difference will be important later.

Banknote quotations during this period were in discounts from or premiums over par. The discount on the notes of a bank at $i$ as quoted in location $j$ is $d_{t}(i, j)=1-p_{t}(i, j)$.

\section{Banknote discounts and bank suspensions}

One implication of the prediction that banknotes were treated as securities is that bank suspensions could have affected the prices of the banknotes. In this section, I develop that implication more fully and compare the resulting predictions with the data. I find that the data are consistent with this prediction.

\section{A. Theory}

When banks at both locations $i$ and $j$ were expected to be redeeming their notes from $t$ through $t^{\prime \prime}, E_{t}\left[q_{t^{\prime}}(i) / q_{t^{\prime \prime}}(j)\right]=1$. Then, (2) and the definition of the discount on a note imply

$$
d_{t}(i, j)=1-g\left[1, \delta_{t}(i, j)\right]=\tilde{d}_{t}(i, j)
$$

I will refer to $\tilde{d}_{t}(i, j)$ as the normal discount on the notes of a bank located at $i$. No presumption is made that this normal discount was constant over time, as the time it took to redeem notes and the costs associated with redemption could have varied over time.

However, when banks in either location were expected to be suspended through $t^{\prime \prime}$, the expectation term in (2) was not necessarily equal to 1 . In this case, the discount on a bank's notes could have differed from the normal discount. 
Two cases are of interest. The first is when banks at $i$ were expected to be suspended at $t^{\prime}$, but local banks were expected to continue to redeem their notes through $t^{\prime \prime}$. In this case $E_{t}\left[q_{t^{\prime}}(i) / q_{t^{\prime \prime}}(j)\right] \leq 1$ because $E_{t}\left[q_{t^{\prime}}(i)\right] \leq 1$ while $E_{t}\left[q_{t^{\prime \prime}}(j)\right]=1$. Then,

$$
d_{t}(i, j) \geq \tilde{d}_{t}(i, j)
$$

The implication is that if banknotes were treated as securities, then during times when local banks were expected to be redeeming their notes, the discounts on the notes of suspended banks should have been at least as large as when they were also redeeming their notes.

The other case of interest is when banks at $i$ were expected to redeem their notes at $t^{\prime}$, but local banks were expected to be suspended at $t^{\prime \prime}$. Using the same logic as above, $d_{t}(i, j) \leq \tilde{d}_{t}(i, j)$ for this case. If banknotes were treated as securities, then during times when local banks were suspended but banks at $i$ were not, the discount on bank $i$ 's notes should have been no greater than when local banks were also redeeming their notes.

It is important to note that the theory does not deliver predictions about the discounts on bank $i$ 's notes when both it and local banks were expected to be suspended. This results from the inclusion of the redemption rate on local banknotes in (1) and is the important difference between this pricing equation and Gorton's mentioned above. Since $E_{t}\left[q_{t^{\prime}}(i)\right] \leq 1$ and $E_{t}\left[q_{t^{\prime \prime}}(j)\right] \leq 1$ in this case, $E_{t}\left[q_{t^{\prime}}(i) / q_{t^{\prime \prime}}(j)\right] \gtreqless 1 .^{9}$

\section{B. Data}

The data of banknote discounts from periods of bank suspensions are consistent with these predictions of the view that banknotes were treated as securities. Discounts on a

\footnotetext{
${ }^{9}$ This implicitly assumes that $q_{t^{\prime}}(n)$ and $q_{t^{\prime \prime}}(j)$ are independent, which seems reasonable when banks in one location are expected to be suspended while banks in another are expected to continue to be redeeming.
} 
bank's notes were generally smaller when the bank was redeeming its notes than when it was suspended and other banks were not.

The period of bank suspensions I examine is from May 1837 until the end of 1842 . The dates of specie payment suspensions and resumptions for banks in the cities of New York, Philadelphia, Baltimore, Charleston, and Cincinnati; for banks in the states of North Carolina and Kentucky; and for the Bank of Virginia in Richmond and the Bank of Louisiana in New Orleans are given in Table 1. The table shows that during several episodes, banks in some of these locations were suspended while banks in other locations were not.

I first consider the evidence from banknote discounts as quoted in New York. During two episodes, banks in New York were redeeming their notes in specie, but banks in some other locations were not: one from May 1838 to August of that year (or December in the case of New Orleans), and a second beginning in October 1839 and lasting until July 1840 (in the case of Charleston), and various times in 1842 for banks in the other locations.

The discounts quoted by New York brokers on the notes of all banks in the other locations listed in Table 1 are shown in Figure 1 for the period 1835 through 1844, one panel per location. (Throughout this discussion, I use the term foreign banks to designate banks in locations other than where the discount is being quoted and local banks to designate banks where the discount is being quoted.) Periods when both foreign and New York banks were redeeming are shown in gray, and periods when foreign banks were suspended and New York banks were redeeming are shown in black. ${ }^{10}$ In dating the observations, I assume that the date of the discount is the date of the publication in which it appears.

\footnotetext{
${ }^{10}$ For completeness, periods when both foreign and New York banks were suspended are shown in dotted light gray. However, these periods are not discussed because, as noted above, the theory does not deliver predictions about banknote discounts during these periods.
} 
Testing whether the discounts in these figures are consistent with the banknotes-assecurities view requires an estimate of $\tilde{d}_{t}(i, j)$, the normal discount on bank $i$ 's notes, for banks in each location. For this I use the average discount on the notes of banks in a particular location for the period between 1835 and 1840 when both those banks and New York banks were redeeming their notes. Obviously, this choice is somewhat arbitrary. My justification is that it covers a long enough period to ensure that the results are not sensitive to a few outliers, but that the period is short enough that the cost of redeeming notes should not have changed very much. ${ }^{11}$ My estimate of $\tilde{d}_{t}(i, j)$ for banks in each location is shown by the black dashed line in each panel of Figure 1. This line is the average of the gray line for the period 1835 to 1840 . For the data to be consistent with the prediction of the banknotes-as-securities view, the discounts in black would always have to lie above this line.

That is true for all cases except the Bank of Louisiana. ${ }^{12}$ The strongest support comes from the discounts on the notes of Philadelphia banks (first panel). The discounts on the notes of Philadelphia banks in the Philadelphia suspended-New York redeeming case not only were always above the dashed line but also were always larger than any discount when banks in both places were redeeming.

For banks in the other locations, excluding the Bank of Louisiana, there were times when the discounts on their notes in the foreign suspended-New York redeeming case were smaller than some of the discounts when banks in both places were redeeming. However,

\footnotetext{
${ }^{11}$ Extending the time period used to estimate $\tilde{d}_{t}(n, j)$ in either direction would only lower the estimate and, as is shown below, would only make the evidence more consistent with the view that prices were determined by net redemption value.

${ }^{12}$ Because the Philadelphia discount quotations for New Orleans banks differ by bank, I chose to use those for the Bank of Louisiana. The discount quotations for New York are for "All New Orleans banks," of which the Bank of Louisiana was one.
} 
these periods were few and short-lived. Further, the large discounts when banks in both places were redeeming mostly occur immediately before times of bank suspensions, and it may not be reasonable to assume that $E_{t}\left[q_{t^{\prime}}(i) / q_{t^{\prime \prime}}(j)\right]=1$ at such times. Hence, I conclude that the evidence for banks in these locations also is consistent with the proposition that banknotes were treated as securities.

The evidence for the Bank of Louisiana (last panel of Figure 1) is less consistent with the banknotes-as-securities view. During two periods, the Bank of Louisiana had suspended while New York banks were redeeming, yet, contrary to the theory, the discounts on its notes fell below the dashed line. These periods occurred from October through December 1838 and from October 1840 to early February 1841. Nonetheless, it is true that when the Bank of Louisiana was suspended but New York banks were not, the vast majority of discounts were larger than when banks in both locations were redeeming.

My conclusion is that, taken as a whole, the evidence from New York shows that discounts on banknotes were greater when banks had suspended specie payments than when they were redeeming their notes and is therefore consistent with the proposition that banknotes were treated as securities.

An interesting regularity also appears in Figure 1. The discounts on the notes of foreign banks always increased when banks in New York suspended payments regardless of whether or not local banks suspended at the same time. The only case for which this did not occur is the Bank of Virginia.

I next consider the evidence from discounts quoted in Philadelphia. Table 1 shows that at a time during 1842, banks in Philadelphia had resumed redeeming their notes, but the Bank of Virginia, the Bank of Louisiana, and banks in Kentucky and North Carolina continued to 
be suspended. The discounts for the period 1835 through 1844 on the notes of the Bank of Virginia and the Bank of Louisiana are shown in Figure 2. I use the same conventions for the lines in these figures as in Figure 1. The results are very similar to those for the discounts as quoted in New York. Specifically, the discounts in black (foreign suspended-Philadelphia redeeming) always lie above the black dashed line (estimate of $\tilde{d}_{t}(i, j)$ ). Thus, I conclude that this evidence on discount quotes from Philadelphia is also consistent with banknotes having been treated as securities.

The evidence presented above is for cases when foreign banks were suspended and local banks were redeeming versus discounts when both were redeeming. Having quotations from Philadelphia permits tests for the opposite case - when Philadelphia banks were suspended but banks in some other locations were not. As noted above, if banknotes were treated as securities, the discounts on notes of redeeming foreign banks should have been no larger during these times than when Philadelphia banks were also redeeming their notes.

I consider three episodes. The first two were when Philadelphia banks had suspended but New York banks had not. These episodes are the same as those considered in the discussion of discount quotes from New York, but I now consider them from the point of view of discounts quoted in Philadelphia. The discounts on the notes of New York banks as quoted in Philadelphia for the period 1835-1844 are shown in the upper panel of Figure 3 (negative discounts are premiums). These discounts are consistent with the predictions of the theory, since they were never larger when Philadelphia banks were suspended than when they were redeeming. In fact, the figure shows that during the second suspension by Philadelphia banks, notes of New York banks commanded a substantial premium in Philadelphia.

The third episode is from July 1840, when Charleston banks resumed specie payments, 
until March 1842 when Philadelphia banks resumed specie payments. The discounts on the notes of Charleston banks as quoted in Philadelphia for 1835-1844 are shown in the lower panel of Figure 3. The evidence here is less favorable to the banknotes-as-securities view than that in the upper panel, but only slightly less so. Until January 1844, the discounts quoted in Philadelphia on the notes of Charleston banks were never less than 1 percent when Philadelphia banks and Charleston banks were both redeeming their notes in specie. However, when Philadelphia banks were suspended and Charleston banks were redeeming, the discount was 1 percent or less except for March and April 1841.

I am able to perform another test of whether redemption rates affected banknote prices as predicted by the banknotes-as-securities view. For the period 1839-1842 I have data on the exchange rate between specie and local bank notes for Philadelphia. Thus, I have data on $q_{t^{\prime \prime}}(j)$ for the period October 1839 to May 1842 during which Philadelphia banks were suspended. Because New York banks were not suspended during this period, it is reasonable to assume that $E_{t}\left[q_{t^{\prime}}(i)\right]=1$ for these banks for this time. As can be seen from (2), an implication of the banknotes-as-securities view is that the price of specie and the price of New York banknotes should have been equal except for redemption costs.

The discounts on New York banknotes and on specie for October 1839 to May 1842 as quoted in Philadelphia are shown in Figure 4. Although the difference between the two series was not constant over time, the two series tracked each other very closely. The correlation is 0.72. I take this as strong evidence in favor of the proposition that banknotes were viewed as securities.

I conclude that taken as a whole, the evidence from the periods when banks in one location were redeeming while banks in another location were not is consistent with the view 
that banknotes were priced as securities during the antebellum period.

\section{Banknote discounts and redemption costs}

If banknotes were treated as securities, then a second prediction is that the discount on a bank's notes should have been positively related to the cost of redeeming its notes, $\delta_{t}(i, j)$. I test this prediction in three ways. The first is by examining whether the discounts on the notes of banks in a particular location changed over time in response to changes in redemption costs. The second is by examining at a point in time the discounts on the notes of a cross section of banks with different redemption costs. The third is by presenting several episodes in which the notes of banks at some distance from the quote location, implying nonzero redemption costs, were nonetheless quoted at par in that location.

To conduct the first two of these tests, I first require a measure of redemption costs. As no direct measures of redemption costs are available, I use the price of a one-way ticket to get from either New York or Philadelphia to some location as a proxy for the cost of redeeming notes of banks in that location. By 1854, this was the price of a railroad ticket in most cases. However, in some cases - for example, getting from Philadelphia to New Yorka steamboat or ferry trip was also involved. Further, getting to Mobile and New Orleans involved taking a stagecoach at least part of the way. Information on the cost of traveling from New York or Philadelphia to various locations is available in Disturnell's Guide through the Middle, Northern, and Eastern States for June 1847 and in Disturnell's Railway and Steamship Guide for July 1854 and January 1855.

Not all of the locations for which I can obtain travel costs are appropriate for conducting these tests, however. The banks in some locations had some type of special note 
redemption arrangements that could have affected the discounts on their notes. Specifically, I eliminated all cities in New England except Boston because of the presence of the Suffolk Banking System, a note-clearing arrangement that virtually all New England banks participated in during this period. While this System was in place, the notes of all New England banks went at par in that region, which meant that the notes of all banks in that region were quoted at the same rate of discount. I also eliminated all cities in the state of New York except Albany. After July 1841, every New York bank was required to have an agent bank in either New York or Albany that would redeem its notes at a discount no greater than one-half percent. I also eliminated virtually all cities in New Jersey because all banks in those cities had par redemption arrangements with banks in either New York or Philadelphia, and I eliminated all cities in Delaware and several cities near Philadelphia because all banks in these cities had par redemption arrangements with banks in that city. Finally, I eliminated all cities in Ohio except Cleveland because according to the General Banking Law of February 24, 1845, "Independent banks were required to redeem each other's notes without discrimination" (Huntington, 1915, p. 426). In the end, I was left with a sample of 34 cities.

Travel cost and discount information for these cities are given in Table 2. The New York discount data are for November 1847 and August 1854. November data was selected because I have data from Taylor's for that date and it is more comparable to the 1854 data, which comes from Thompson's, than are the other data for 1847 that I have. The reason is that both Taylor and Thompson were in the exchange brokering business, whereas the other discount data for 1847 are from newspapers. August is the only month for which I have any New York data for 1854. For Philadelphia, the discount data are for June 1847 and July 1854. 
To conduct these tests, it also is necessary to determine that it is reasonable to assume that $E_{t}\left[q_{t^{\prime}}(i) / q_{t^{\prime \prime}}(j)\right]=1$, so that differences in discounts are due to differences in redemption costs rather than differences in expected redemption rates. To determine whether this assumption is reasonable for 1847 and 1854, I present in Table 3 evidence on the bank failure experience of each of these 34 locations for 1845 through 1856.

The table shows that it is reasonable to assume that par redemption was expected for the notes of banks in each of these locations throughout this period, so that $E_{t}\left[q_{t^{\prime}}(i) / q_{t^{\prime \prime}}(j)\right]=$ 1 for 1847 and 1854. Out of the 81 banks that existed in New York and Philadelphia at some point in time during this period, only one failed in New York and none failed in Philadelphia. For the other locations, 22 locations had no failures between 1845 and 1856, and another 8 had only 1 failure. The only locations with more than one failure were New Orleans $(2 / 10)$ and Chicago $(3 / 10)$.

\section{A. Differences across time for banks at a location}

If the cost of redeeming the notes of banks in location $i$ was lower at time $t_{2}$ than at $t_{1}$, the banknotes-as-securities view predicts that $d_{t_{2}}(i, j)<d_{t_{1}}(i, j)$. In other words, the discounts on the notes of banks in location $i$ should have fallen when the cost of redeeming notes from banks in that location fell. I find that the data are consistent with this prediction for the most part.

An examination of Table 2 shows that travel costs were generally unchanged or lower in 1854 than they were in 1847, and in some cases they were markedly lower. This is consistent with the general impression that a general decline in transportation costs occurred from the mid-1840s to the mid-1850s, primarily due to the expansion of railroads. Comparing discounts 
for the 30 locations for which I have banknote discount quotes for both 1847 and 1854, I find that the discounts on the notes of banks in 27 of these locations quoted in New York were the same or lower in August 1854 than they were in November 1847. For discounts quoted in Philadelphia, those for the banks in 21 locations were the same or lower in July 1854 than they were in June $1847 .^{13}$

\section{B. Differences across banks at a point in time}

When the notes of banks in location $n$ were more costly to redeem from location $j$ than were the notes of banks in location $i$, the banknotes-as-securities view predicts that $d_{t}(i, j)<d_{t}(n, j)$; that is, the discount of the notes of banks in $i$ should have been lower than the discount on the notes of banks in $n$. I find that the data are generally consistent with this prediction.

Discounts quoted in New York and Philadelphia are plotted against travel costs for 1847 and 1854 in Figure 5. All plots have an observation at the origin because when local banks were redeeming, their notes were quoted at par. (The lines in the figure are the predicted values from a linear regression constrained to go through the origin.) The correlations are 0.35 (New York, 1847), 0.73 (New York, 1854), 0.42 (Philadelphia, 1847), and 0.61 (Philadelphia, 1854), implying that discounts were greater the larger the travel costs, which is consistent with the view that banknotes were treated as securities.

However, the strength of this evidence as support for the banknotes-as-securities view is weakened by the several cases in which there were large differences in travel costs with little or no difference in discounts. One case occurs in 1847 in New York. The costs of getting

\footnotetext{
${ }^{13}$ I ignore quotes for banks in the same location as the quotes because the cost of redeeming local banknotes is assumed to have always been zero.
} 
from New York to Ellicott's Mills and Frederick, both in Maryland, were $\$ 6.78$ and $\$ 7.85$, respectively. The cost of getting to New Orleans was $\$ 68.50$. Yet, the notes of banks in all three locations were quoted at a 1 percent discount in New York. Another case occurs in Philadelphia in that year. The cost of getting from Philadelphia to Wheeling, Virginia, was $\$ 14.00$, and the cost of getting to New Orleans was $\$ 65.50$. Yet, the notes of banks in both locations were quoted at a 1 percent discount.

Two more cases occur in 1854. In that year, it cost $\$ 11.00$ to get from New York to Cleveland and $\$ 55.42$ to get to New Orleans. Yet, notes of banks in both locations were quoted at a 2 percent discount in New York. In the same year it cost $\$ 12.00$ to get from Philadelphia to Detroit and $\$ 52.42$ to get from Philadelphia to New Orleans. Yet, the notes of banks in both locations were quoted at a 1.75 percent discount in Philadelphia. ${ }^{14}$

Figure 5 also shows cases in which there were large differences in discounts with little or no difference in travel costs. For example, in 1854 , it cost $\$ 11$ to get from New York to Pittsburgh; Cumberland, MD; or Cleveland. Yet the average annual quoted discounts on the notes of banks in these locations ranged from 0.75 percent (Cumberland and Pittsburgh) to 2 percent (Cleveland). The same types of differences also appear in the discounts in New York for 1847 and for those quoted in Philadelphia for both 1847 and 1854.

\footnotetext{
${ }^{14}$ Unfortunately, I have been able to find travel cost data only for 1847 and 1854, so I cannot determine how discounts and travel costs were related in other years. Since distance and travel cost were highly correlated in 1847 and 1854, however, distance may be a good proxy for travel costs during the first half of this century. Thus, I examined the relationship between bank note discounts and distance for 1827 and 1836 for New York and for 1836 for Philadelphia. (Discount quotes for Philadelphia are not available for 1827.) I chose these years to have observations at roughly 10-year intervals, so that I have one entry for each decade beginning with 1827. However, I chose 1836 instead of 1837 to avoid the panic beginning in May of that year (see Table 1). The results are shown in Figure A1 in the Appendix and are consistent with those for the later years. Discounts on notes generally increased with the distance of the issuing bank from the location in which the discount was being quoted. However, once again, sometimes there were large differences in discounts without there being large differences in distance. The exception here is the result for discounts quoted in Philadelphia in 1836, which include no large outliers.
} 
The above discussion, by focusing solely on the relationship between discounts and travel cost, implicitly assumes that each dollar of banknotes purchased by a broker had the same cost of being sent back to the issuing bank. This assumption may not be reasonable. The volume of notes purchased by brokers and sent for redemption may have differed by location of the issuing bank, so that the average cost of note redemption may not have been linear in travel cost. Further, notes came in different denominations. So, if what mattered for the cost of redemption was the number of pieces of paper, not their dollar value, then, once again, redemption costs may not have been the same per dollar of notes. ${ }^{15}$

I am unable to obtain any information on the volume or total value of notes purchased by brokers in either New York or Philadelphia. However, if the volume or total value of notes that banks in a particular location presented to brokers in New York and Philadelphia was positively related to the total note circulation of the banks in that location, then average redemption costs should have been declining functions of these variables.

To determine whether this was the case, I regressed discounts in New York and Philadelphia on log total circulation and log travel costs for both 1847 and 1854 . For all four regressions, the estimated coefficient had the correct sign; the estimated coefficients on $\log$ travel costs were positive and the coefficients on log circulation were negative. However, although estimated coefficients on log travel costs were always significant at better than the 1 percent level, the estimated coefficients on log circulation were significant at the 5 percent level only in the 1847 New York regression. The explanation power of the regressions was relatively low. The adjusted $R^{2}$ was 0.55 and 0.57 for the New York regressions for 1847 and

\footnotetext{
${ }^{15}$ The banknote reporters reveal some evidence that small denomination notes were not purchased by brokers or carried higher discounts than large denomination notes.
} 
1854, respectively, and 0.28 and 0.42 for those for Philadelphia for the same years.

Thus, I conclude that this evidence provides only weak support for the view that banknotes were priced as securities. Although discounts tended to increase with redemption costs, the relationship was not tight.

\section{Distant banks' notes quoted at par}

Other than exceptional cases of special arrangements regarding banknote redemption, like the Suffolk Banking System mentioned above, the banknotes-as-securities view predicts that notes of banks located at a considerable distance from the quote location - so that it is reasonable to assume that redemption costs were not zero- should go at discount. They should not circulate at par. The strongest evidence against banknotes being priced as securities comes from the fact that in numerous instances this was not the case. Notes of distant banks circulated at par in some quote locations.

One set of evidence comes from the quotes from Philadelphia. The notes of banks in New York were quoted at par in Philadelphia from March 1844 through December 1847, and again from February 1850 through December 1851. In contrast, the notes of Philadelphia banks were quoted at a discount in New York during these periods.

A second set of evidence comes from the quotes from Cincinnati. The notes of banks in Boston, New York, and St. Louis were quoted at par in Cincinnati from July 1845 through

June 1847; the notes of Philadelphia banks, from September 1847 through June 1847; and the notes of Baltimore banks, from November 1845 through June 1847. In addition, the notes of banks in all of those cities were quoted at par in Cincinnati in January and February 1856, as were the notes of banks in New Orleans and all other banks in Massachusetts. Once again, 
the comparison is asymmetric in that the notes of Cincinnati banks were always quoted at a discount in both New York and Philadelphia.

A third set of evidence comes from quotes from Cleveland. The notes of banks in Boston, New York, and Philadelphia were quoted at par in Cleveland in January, June, and September 1856, and the notes of banks in Baltimore were quoted at par in June and September of that year. As was the case for Cincinnati, the notes of Cleveland banks were always quoted at a discount in both New York and Philadelphia.

It should be noted that notes of distant banks may have been quoted at par in Cincinnati and Cleveland at other times. I can report only about the dates listed because I have been able to obtain only incomplete data for these two cities, as is described in the Appendix.

\section{Conclusion}

Before 1860, a large number of currencies circulated in the United States. These were the notes issued by the numerous state-chartered banks that existed during this period. In general, these notes did not circulate at par against each other, and the exchange rates among these various currencies varied over time. I have here examined the determinants of the prices of these notes in the notes of banks in New York, Philadelphia, Cincinnati, and Cleveland. Specifically, this paper examines the proposition that banknotes were treated by the public as securities.

I find some evidence consistent with the view that banknotes were considered to be securities. First, I find that banknote prices generally responded to changes in expectations concerning the amount of specie for which they could be redeemed, as the proposition predicts. When banks had temporarily suspended specie payments, the discounts on their notes were 
larger than when they were redeeming their notes in specie on demand and prices tended to track movements in banknote-specie exchange rates. Second, I find that the discounts on banknotes were positively related to the cost of getting to the issuing bank from the location of the banknote price quote.

However, I also find evidence inconsistent with the proposition. First, I find that the relationship between banknote prices and redemption costs was not tight. Redemption costs are able to explain no more than 50 percent of the variable in quoted discounts. Second, I find that in numerous instances, the notes that should have been costly to redeem because the issuing bank was located at a considerable distance from the quote location nonetheless were quoted at par.

My conclusion from the empirical evidence is that the proposition that banknotes were priced to equal their net expected redemption value is only weakly supported by the evidence. To more fully understand how banknote prices were determined during this period, we need a richer theory. Based on the empirical evidence presented here, I would argue that such a theory should take into account not only that the suspension of specie payments affected the price of banknotes, but also that notes of different banks could have different degrees of acceptability in different transactions. This richer theory is needed before one can answer the question of whether a uniform currency would have been a welfare improvement on the state banknote currency. 


\section{References}

Cole, Arthur Harrison. 1938. Wholesale commodity prices in the United States, 1700-1861. Statistical supplement, actual wholesale prices of various commodities. Cambridge, Mass.: Harvard University Press.

Dillistin, William H. 1949. Bank note reporters and counterfeit detectors, 1826-1866. New York: American Numismatic Society.

Disturnell, John. 1847. Disturnell's guide through the middle, northern, and eastern states. (June) New York: J. Disturnell.

Disturnell, John. 1854. Disturnell's railway and steamship guide. (July) New York: J. Disturnell.

Disturnell, John. 1855. Disturnell's railway and steamship guide. (January) New York: J. Disturnell.

Gorton, Gary. 1999. Pricing free bank notes. Journal of Monetary Economics 44 (1, August) $33-64$.

Huntington, C. C. 1915. A history of banking and curency in Ohio before the Civil War. Ohio Archaeological and Historical Quarterly 24 (3, July) 235-539.

Krooss, Herman Edward. 1969. Documentary history of banking and currency in the United States. New York: Chelsea House.

Matsuyama, Kininori, Nobuhiro Kiyotaki, and Akihiko Matsui. 1993. Toward a theory of international currency. Review of Economic Studies 60, 283-307.

McCusker, John J. 1992. How much is that in real money? A historical price index for use as a deflator of money values in the economy of the United States. Worcester, Mass.: 
American Antiquarian Society.

Ravikumar, B., and Neil Wallace. 2001. A benefit of uniform currency. Manuscript, Pennsylvania State University.

Wallace, Neil. 2003. Commentary. In Evolution and procedures in central banking, David E. Altig and Bruce D. Smith, eds., 256-62. Cambridge: Cambridge University Press. 
Table 1: Bank suspensions, 1837 - 1842

\begin{tabular}{|c|c|c|c|c|}
\hline \multirow[b]{2}{*}{ Location } & \multicolumn{2}{|c|}{ first suspension } & \multicolumn{2}{|c|}{ second suspension } \\
\hline & begin & end & begin & end \\
\hline New York & May 10,1837 & May 9, 1838 & & \\
\hline Philadelphia & May 11,1837 & Aug 12, 1838 & Oct 9, 1839 & Mar 16, 1842 ** \\
\hline Baltimore & May 11,1837 & Aug 12, 1838 & Oct 10, 1839 & Mar 17,1842 ** \\
\hline Charleston & May 17,1837 & Aug 31, 1838 & Oct 14,1 & July 20, 1840 \\
\hline Cincinnati & May 17,1837 & Aug 12, 1838 & Oct 14, 1839 & Feb 18, 1842 \\
\hline North Carolina & May 18,1837 & July 31, 1838 & Oct 9, 1839 & June, 1842 \\
\hline Kentucky & May 19,1837 & Aug 12, 1838 & Oct 16,1839 & June, 1842 \\
\hline Bank of Virginia & May 15,1837 & Aug 12, 1838 & Oct 12, 1839 & Sep 14,1842 * \\
\hline Bank of Louisiana & May 13,1837 & Dec 23, 1838 & Oct 18, 1839 & Dec 4, 1842 \\
\hline
\end{tabular}


Table 2: Discounts, travel cost, circulation, and population by location, 1847 and 1854

\begin{tabular}{|c|c|c|c|c|c|c|c|c|c|c|c|}
\hline \multirow[b]{2}{*}{ Location } & \multicolumn{2}{|c|}{$\begin{array}{l}\text { Average discount } \\
\text { in New York (\%) }\end{array}$} & \multicolumn{2}{|c|}{$\begin{array}{l}\text { Travel cost from } \\
\text { New York (\$) }\end{array}$} & \multicolumn{2}{|c|}{$\begin{array}{c}\text { Average discount } \\
\text { in Philadelphia (\%) }\end{array}$} & \multicolumn{2}{|c|}{$\begin{array}{l}\text { Travel cost from } \\
\text { Philadelphia (\$) }\end{array}$} & \multicolumn{2}{|c|}{$\begin{array}{l}\text { Total bank circ. } \\
\text { (\$ millions) }\end{array}$} & \multirow{2}{*}{$\begin{array}{l}\text { Population } \\
1850\end{array}$} \\
\hline & 1847 & 1854 & 1847 & 1854 & 1847 & 1854 & 1847 & 1854 & 1847 & 1854 & \\
\hline Mobile, AL & 1.50 & 2.00 & 63.50 & 50.42 & 1.75 & 1.75 & 60.50 & 47.42 & 2.13 & 3.07 & 20,515 \\
\hline Washington, DC & 1.00 & 0.75 & 7.60 & 7.25 & 0.50 & 0.50 & 4.60 & 4.25 & & & 40,001 \\
\hline Atlanta, GA & & 1.25 & & 33.67 & & 5.00 & & 30.67 & 0.00 & 0.69 & 2,572 \\
\hline Augusta, GA & 1.50 & 1.25 & 33.00 & 28.67 & 1.25 & 1.00 & 30.00 & 25.67 & 1.34 & 2.16 & 9,448 \\
\hline Savannah, GA & 1.50 & 1.25 & & 33.07 & 1.25 & 1.00 & & 30.07 & 1.64 & 3.51 & 15,312 \\
\hline Chicago, IL & & 1.25 & & 18.50 & & 1.75 & & 18.00 & 0.00 & 0.73 & 29,963 \\
\hline Indiana (State Bank) & 2.00 & 2.00 & & 17.00 & 1.25 & 1.75 & & 15.25 & 3.61 & 2.80 & 8,181 \\
\hline Lexington, $\mathrm{KY}$ & 2.00 & 2.00 & & 21.00 & 1.25 & 1.50 & & 20.25 & 2.34 & 2.70 & 8,159 \\
\hline Louisville, KY & 2.00 & 2.00 & & 18.00 & 1.25 & 1.50 & & 17.25 & 3.37 & 4.79 & 43,194 \\
\hline New Orleans, LA & 1.00 & 2.00 & 68.50 & 55.42 & 1.00 & 1.75 & 65.50 & 52.42 & 4.10 & 6.92 & 116,375 \\
\hline Boston, MA & 0.25 & 0.25 & 4.00 & 4.00 & 0.50 & 0.38 & 7.00 & 7.00 & 7.06 & 8.56 & 136,881 \\
\hline Annapolis, MD & 1.00 & 1.00 & 7.50 & 7.85 & 0.50 & 0.50 & 4.50 & 4.85 & 0.25 & 0.07 & 3,011 \\
\hline Baltimore, MD & 0.38 & 0.38 & 6.00 & 6.00 & 0.13 & 0.25 & 3.00 & 3.00 & 1.99 & 2.96 & 169,054 \\
\hline Cumberland, MD & 2.00 & 0.75 & 13.00 & 11.00 & 0.75 & 0.50 & 10.00 & 8.00 & 0.16 & 0.23 & 6,073 \\
\hline Ellicott's Mills, MD & 1.00 & & 6.38 & 6.50 & 0.13 & & 3.38 & 3.50 & 0.06 & & 847 \\
\hline Frederick, MD & 1.00 & 1.00 & 7.85 & 8.15 & 0.50 & 0.50 & 4.85 & 5.15 & 0.08 & 0.30 & 6,028 \\
\hline Hagerstown, MD & 1.00 & 1.00 & & 8.52 & 0.50 & 0.50 & & 5.52 & 0.24 & 0.37 & 3,879 \\
\hline Detroit, MI & 3.00 & 1.25 & 21.00 & 12.50 & 5.00 & 1.75 & 24.00 & 12.00 & 0.36 & 0.76 & 21,019 \\
\hline St. Louis, MO & 2.00 & 1.50 & & 26.50 & 1.25 & 1.00 & & 24.00 & 2.40 & 2.14 & 77,860 \\
\hline Wilmington, NC & 2.00 & 1.75 & 21.00 & 19.50 & 1.50 & 1.50 & 18.00 & 18.25 & 1.72 & 2.52 & 7,264 \\
\hline Paterson, NJ & 0.25 & 0.25 & 0.50 & 0.50 & 0.50 & 0.50 & 3.50 & 3.50 & 0.13 & 0.01 & 11,334 \\
\hline Albany, NY & 0.25 & 0.25 & & 2.50 & 0.50 & 0.50 & & 5.50 & 1.20 & 0.95 & 50,763 \\
\hline New York, NY & 0.00 & 0.00 & 0.00 & 0.00 & 0.00 & 0.13 & 3.00 & 3.00 & 5.90 & 7.83 & 515,547 \\
\hline Cleveland, $\mathrm{OH}$ & 1.50 & 2.00 & & 11.00 & 1.25 & 1.50 & & 10.00 & 0.44 & 0.72 & 17,034 \\
\hline Chambersburg, PA & 1.25 & 0.75 & & 7.52 & 0.75 & 0.75 & & 4.52 & 0.25 & 0.34 & 3,335 \\
\hline Harrisburg, PA & 1.50 & 0.75 & 7.00 & 5.40 & 0.75 & 0.63 & 4.00 & 2.40 & 0.36 & 0.57 & 7,834 \\
\hline Philadelphia, PA & 0.25 & 0.25 & 3.00 & 3.00 & 0.00 & 0.00 & 0.00 & 0.00 & 5.12 & 5.05 & 340,045 \\
\hline Pittsburgh, PA & 1.50 & 0.75 & 16.00 & 11.00 & 0.63 & 0.63 & 13.00 & 8.00 & 1.36 & 1.29 & 46,601 \\
\hline York, PA & 1.25 & 0.75 & & 6.25 & 0.75 & 0.63 & & 3.25 & 0.33 & 0.83 & 1,960 \\
\hline Charleston, SC & 1.50 & 1.25 & 27.00 & 30.14 & 1.25 & 0.88 & 24.00 & 25.39 & 2.40 & 4.09 & 42,985 \\
\hline Nashville, TN & 3.00 & 3.00 & & 41.92 & 2.25 & 2.25 & & 38.92 & 4.39 & 6.33 & 10,165 \\
\hline Norfolk, VA & 1.25 & 1.25 & 11.00 & 13.00 & 0.88 & 1.13 & 8.00 & 10.00 & 1.09 & 2.25 & 14,326 \\
\hline Richmond, VA & 1.25 & 1.25 & 13.00 & 11.00 & 0.88 & 0.50 & 10.00 & 8.00 & 5.27 & 5.19 & 27,570 \\
\hline Wheeling, VA & 2.00 & 1.25 & 17.00 & 14.50 & 1.00 & 1.13 & 14.00 & 11.50 & 0.87 & 3.15 & 11,435 \\
\hline
\end{tabular}


Table 3: State bank failures by location, 1782 - 1856

\begin{tabular}{|c|c|c|c|c|c|}
\hline \multirow[b]{2}{*}{ Location } & \multicolumn{2}{|c|}{$1845-1856$} & \multicolumn{2}{|c|}{$1782-1856$} & \multirow[b]{2}{*}{ comments } \\
\hline & $\begin{array}{c}\text { number of } \\
\text { banks }\end{array}$ & failures & $\begin{array}{c}\text { number of } \\
\text { banks }\end{array}$ & failures & \\
\hline Mobile, AL & 2 & $\begin{array}{r}0 \\
\end{array}$ & 3 & 1 & only failure in 1842 \\
\hline Washington, DC & 8 & 1 & 16 & 5 & only failure in 1852 ; little information about bank \\
\hline Atlanta, GA & 2 & 0 & 2 & 0 & only failure in 1856 \\
\hline Augusta, GA & 6 & 0 & 8 & 2 & failures in 1832,1833 \\
\hline Savannah, GA & 9 & 0 & 8 & 0 & \\
\hline Chicago, IL & 10 & 3 & 10 & 3 & first bank in 1851; first failure 11/20/1854 \\
\hline Indiana (State Bank) & 1 & 0 & 1 & 0 & \\
\hline Lexington, $\mathrm{KY}$ & 1 & 0 & 2 & 1 & only failure in 1819 \\
\hline Louisville, KY & 2 & 0 & 2 & 0 & \\
\hline New Orleans, LA & 10 & 2 & 22 & 4 & \\
\hline Boston, MA & 38 & 1 & 49 & 5 & \\
\hline Annapolis, MD & 1 & 0 & 1 & 0 & \\
\hline Baltimore, MD & 15 & 0 & 19 & 2 & \\
\hline Cumberland, MD & 2 & 0 & 3 & 0 & \\
\hline Ellicott's Mills, MD & 1 & 0 & 1 & 0 & bank closed in 1852 \\
\hline Frederick, MD & 3 & 0 & 3 & 0 & \\
\hline Hagerstown, MD & 2 & 1 & 3 & 2 & \\
\hline Detroit, MI & 4 & 1 & 9 & 2 & \\
\hline St. Louis, MO & 1 & 0 & 4 & 2 & \\
\hline Wilmington, NC & 3 & 0 & 3 & 0 & \\
\hline Paterson, NJ & 2 & 1 & 5 & 1 & \\
\hline Albany, NY & 11 & 1 & 11 & 1 & only failure in 1848 \\
\hline New York, NY & 64 & 1 & 78 & 8 & \\
\hline Cleveland, $\mathrm{OH}$ & 4 & 1 & 7 & 4 & \\
\hline Chambersburg, PA & 1 & 0 & 1 & 0 & \\
\hline Harrisburg, PA & 1 & 0 & 1 & 0 & \\
\hline Philadelphia, PA & 17 & 0 & 18 & 1 & \\
\hline Pittsburgh, PA & 4 & 0 & 5 & 1 & \\
\hline York, PA & 2 & 0 & 2 & 0 & \\
\hline Charleston, SC & 9 & 0 & 9 & 0 & \\
\hline Nashville, TN & 10 & 1 & 13 & 3 & \\
\hline Norfolk, VA & 1 & 0 & 1 & 0 & \\
\hline Richmond, VA & 2 & 0 & 2 & 0 & \\
\hline Wheeling, VA & 4 & 0 & 4 & 0 & \\
\hline Totals & 253 & 14 & 326 & 48 & \\
\hline
\end{tabular}


Figure 1: Discounts on selected banknotes as quoted in New York, 1835-1844
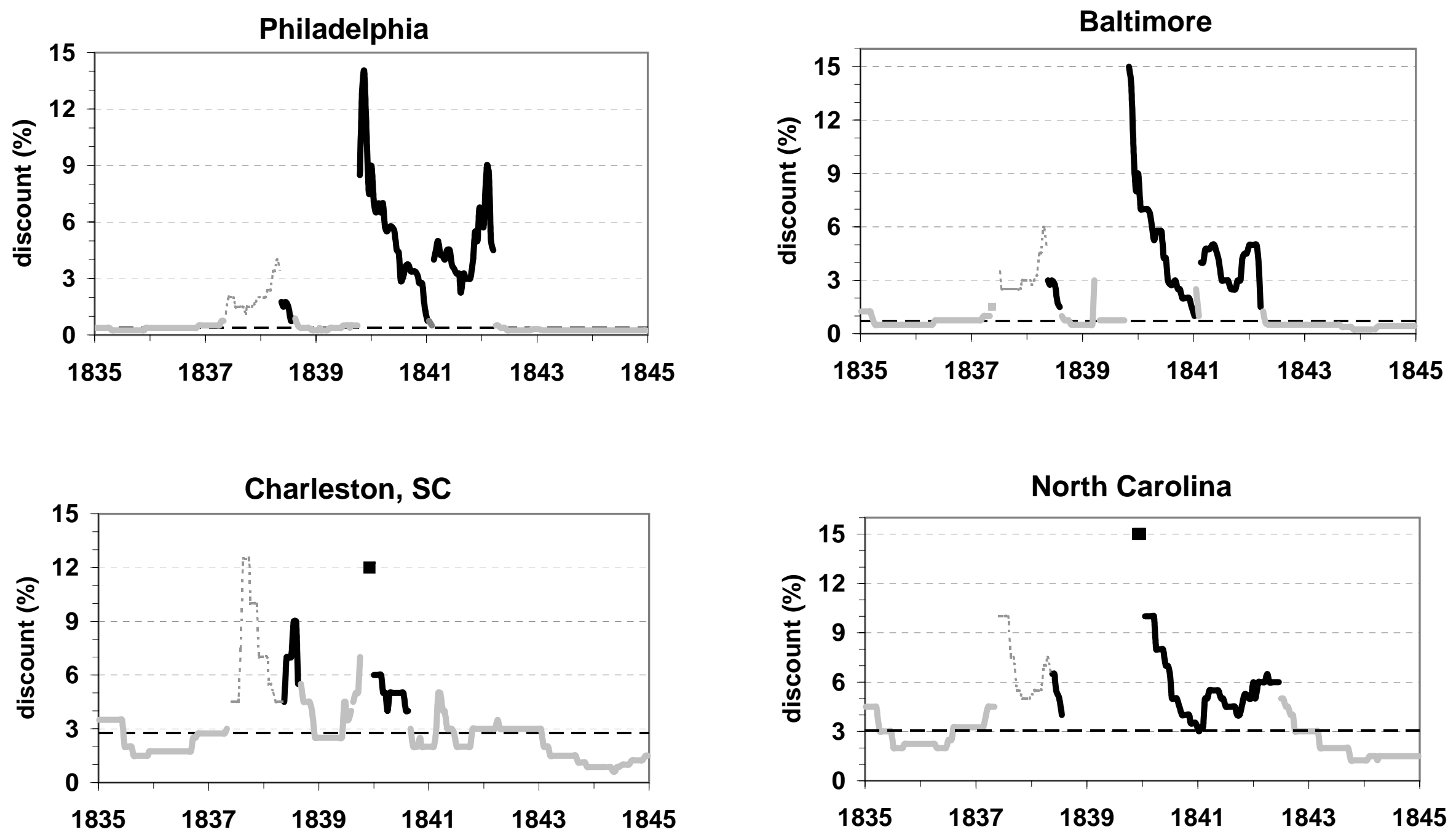
Figure 1: (continued)
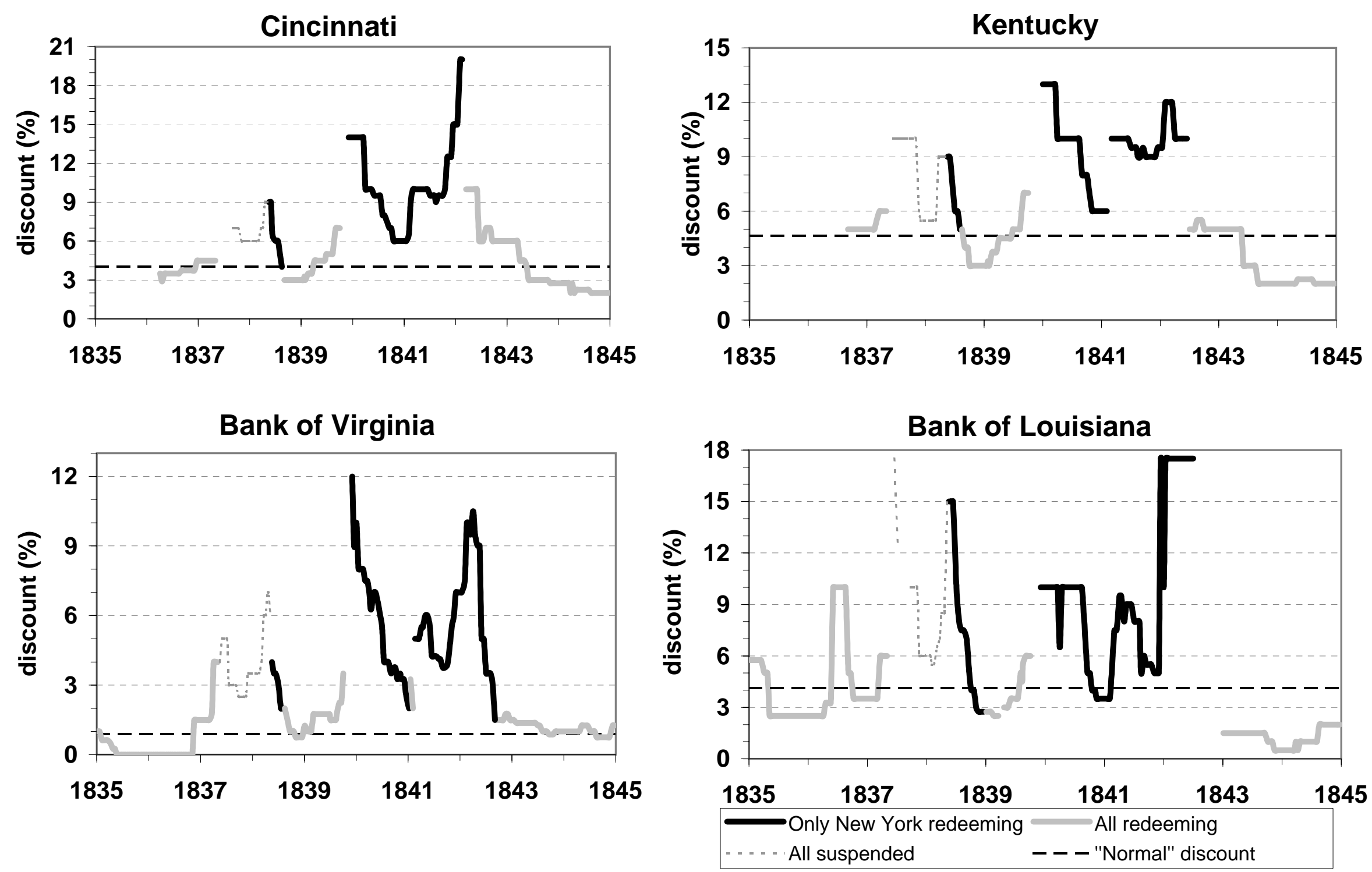
Figure 2: Discounts on selected banknotes as quoted in Philadelphia, 1835-1844
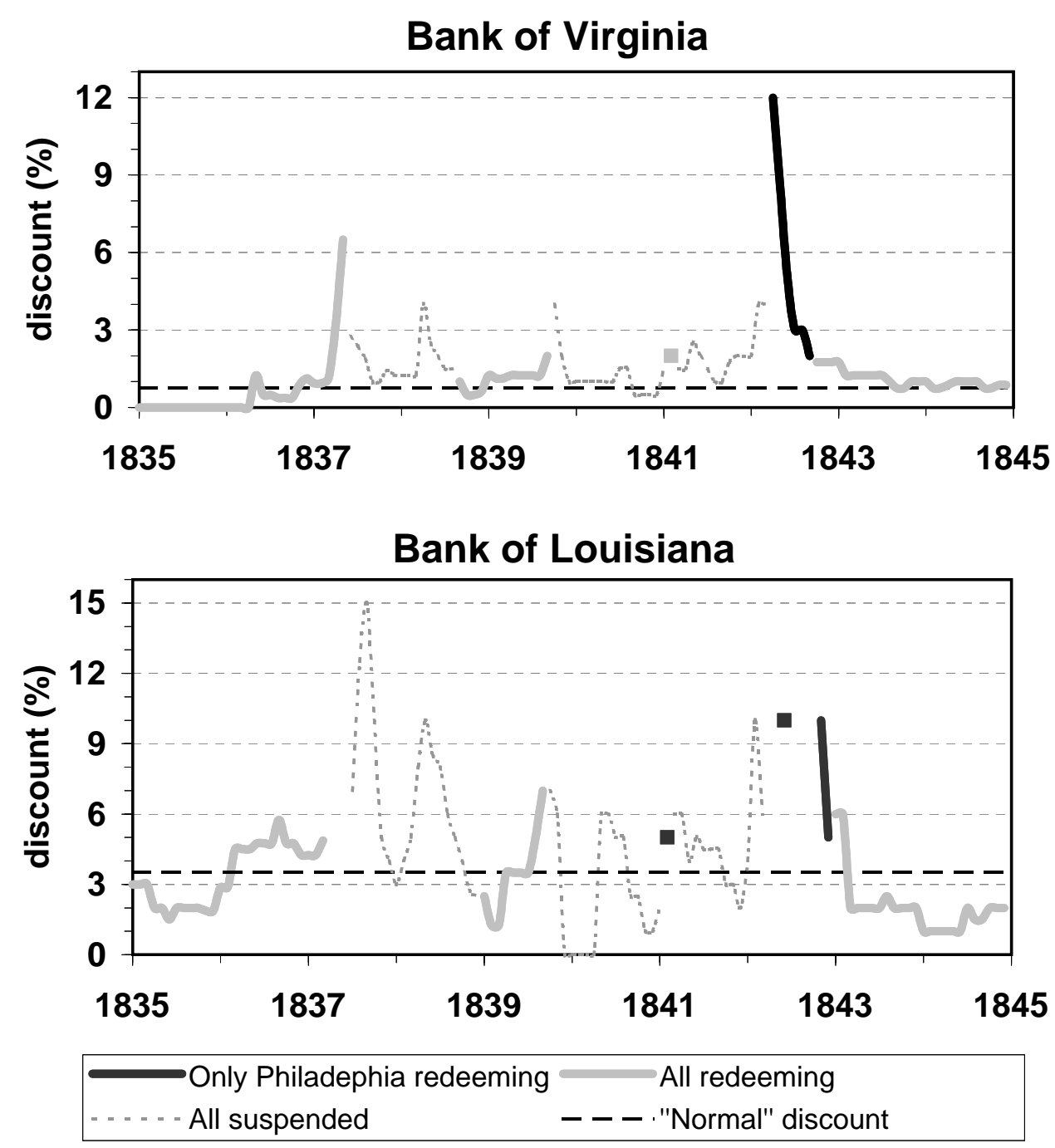
Figure 3: Discounts on selected banknotes as quoted in Philadelphia, 1835-1844
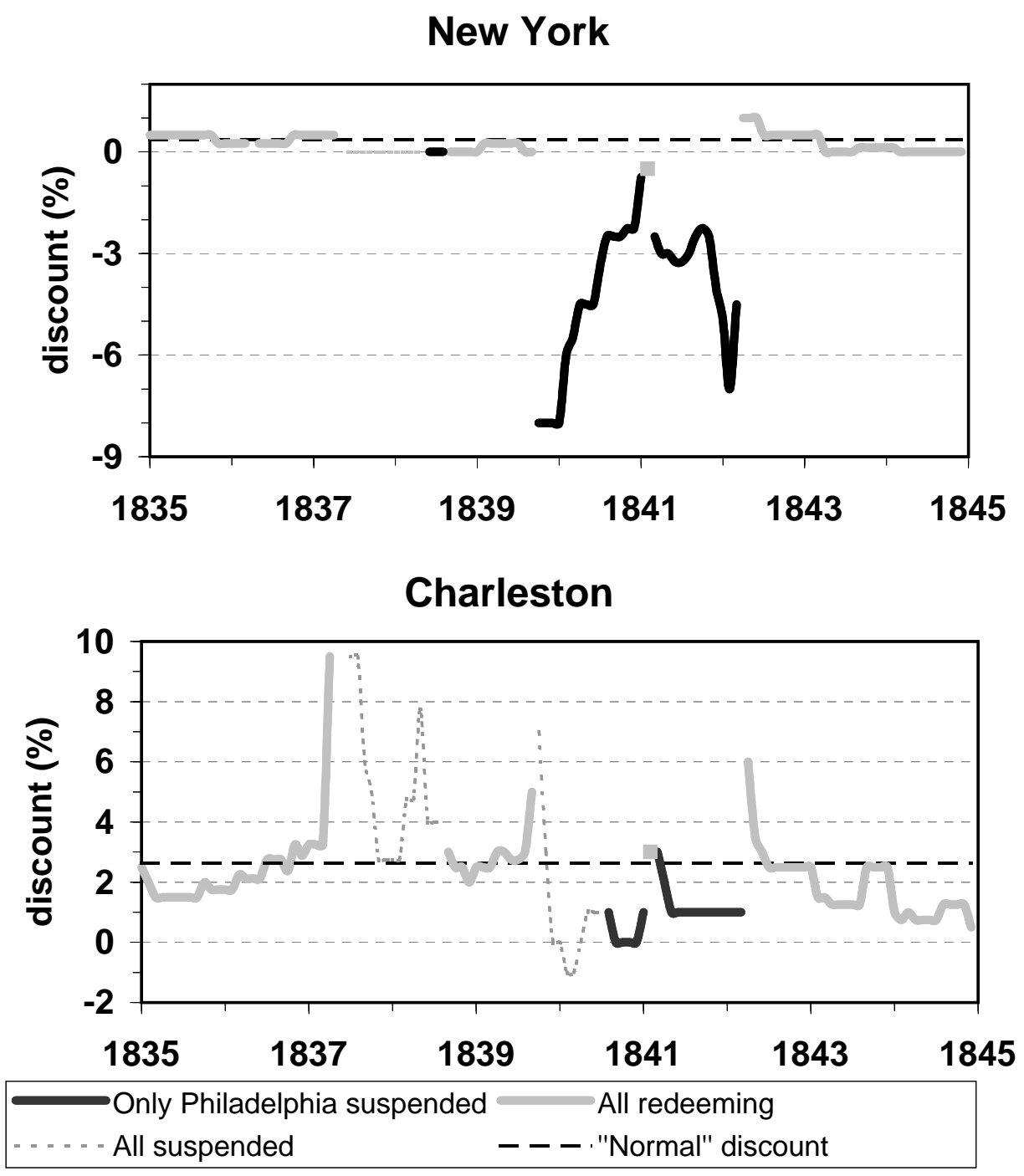
Figure 4: Discounts on notes of New York banks and specie as quoted in Philadelphia, 1839-1842

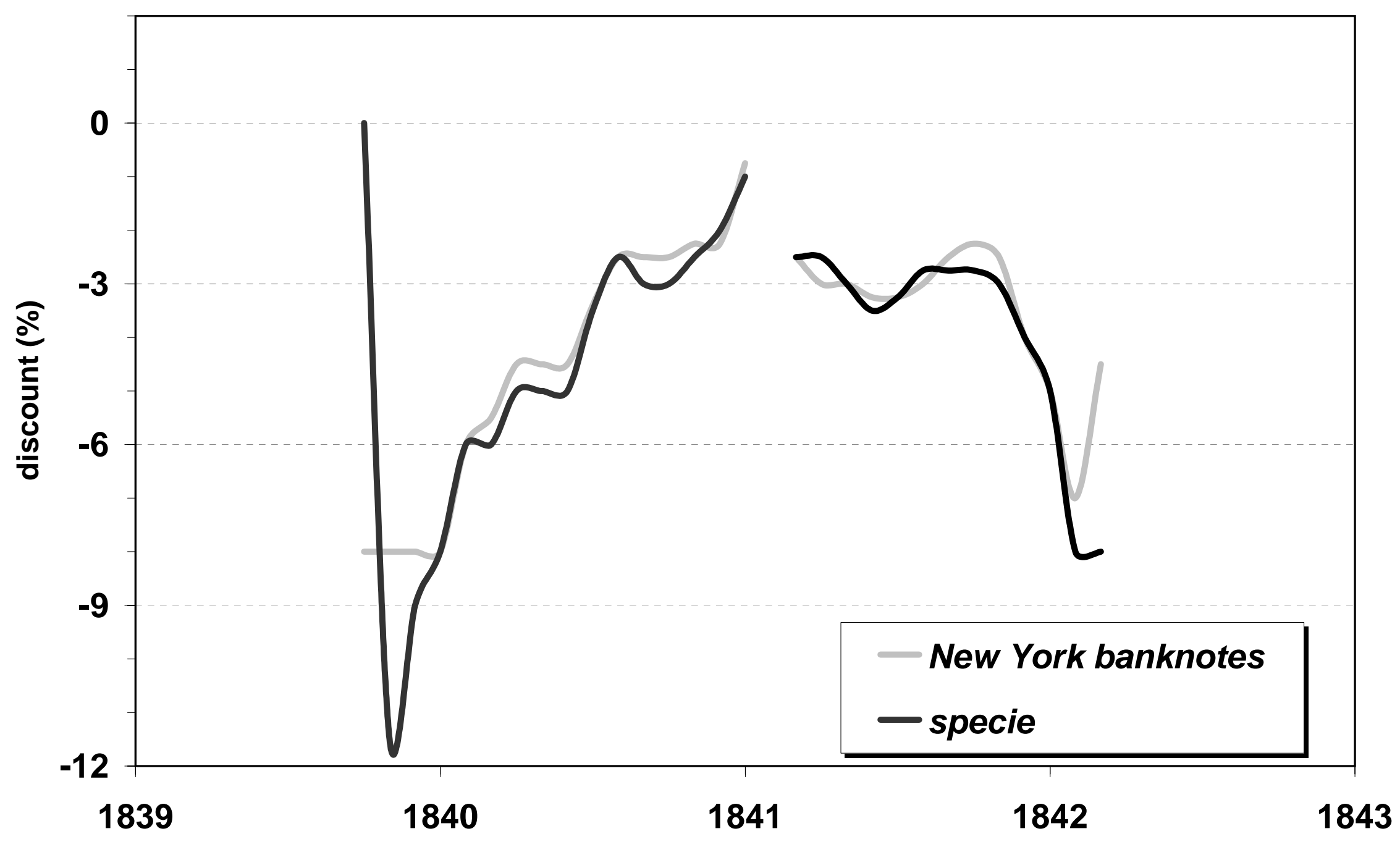


Figure 5: Discounts on banknotes versus travel cost by city
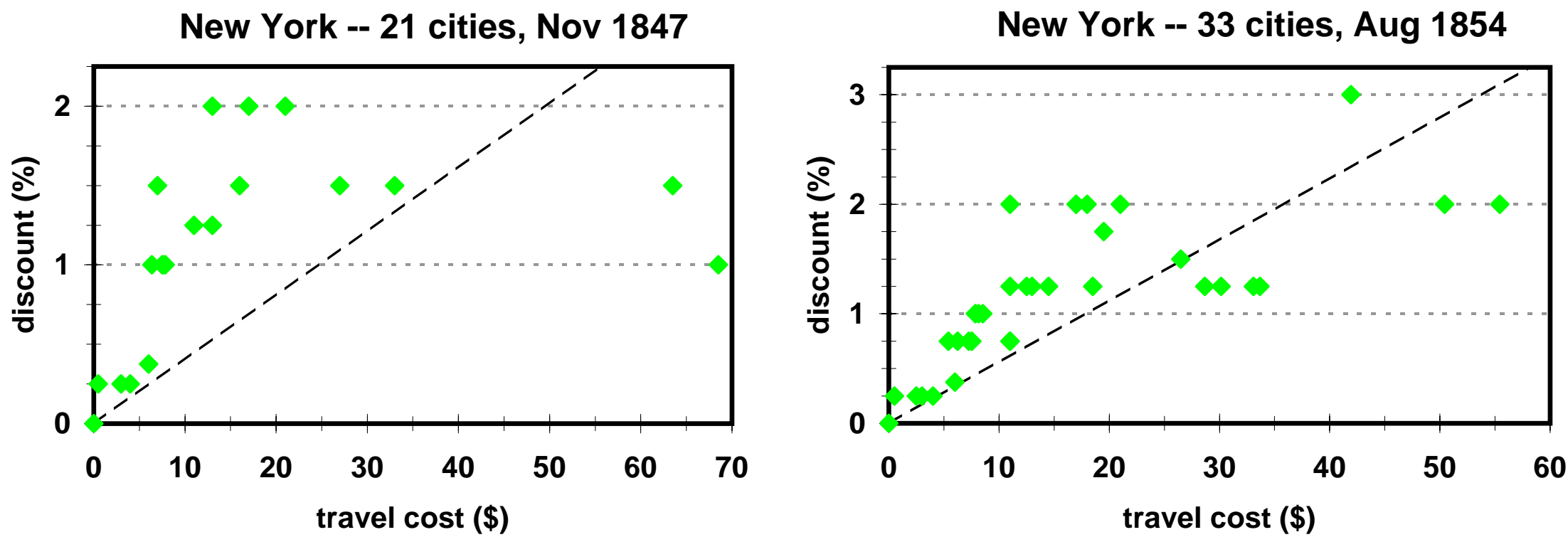

Philadelphia -- 21 cities, June 1847
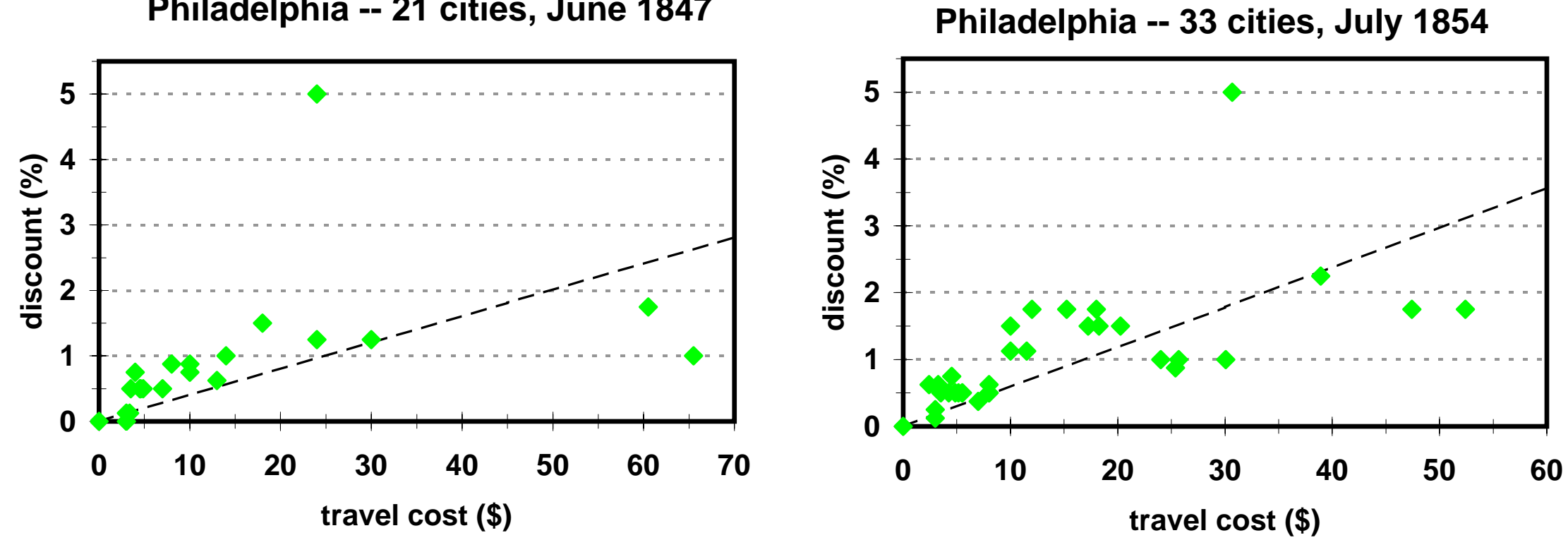


\section{Appendix}

\section{A. Data sources}

The data for this study are discounts or premiums on the notes of individual U.S. state banks as quoted in four locations: New York, Philadelphia, Cincinnati, and Cleveland. Overall, the data cover the period 1817-58. All data used in this study are available at my website: http://minneapolisfed.org/research/economists/ wewproj.html.

I have collected bimonthly data for New York for the period from July 1817 through December 1849 and monthly data for the period from January 1850 through November 1852 from the Shipping \& commercial list (and New-York price current). This source also has observations for October and November 1853 and for July, August, and December 1856. In addition, I have data for January 15, 1847, and for November 23, 1847 from Taylor's United States Money Reporter and Gold and Silver Coin Examiner. I also have data for November 1853, August 1854, December 1855, all months of 1857 except March, and June 1858 from Thompson's Bank Note and Commercial Reporter (Thompson's). ${ }^{16}$

The data for Philadelphia are monthly for the period from August 1830 through January 1831 and from August 1832 through December 1858. The data through January 1839 are from Bicknell's Reporter, Counterfeit Detector, and General Prices Current (Bicknell's). The later data are all from Van Court's Counterfeit Detector and Bank Note List (Van Court's). ${ }^{17}$

For Cincinnati, I have observations for February 1841 and for the period from July 1845 through June 1847 from Goodman's Western Counterfeit Detector and Bank Note Table.

\footnotetext{
${ }^{16}$ Actually, Thompson's had several titles during this period. See Dillistin (1949, pp 83-93) for a discussion.

${ }^{17}$ These publications also had several different titles during these periods. See Dillistin (1949, pp 126, 132-134) for a discussion.
} 
In addition, I have data for February 1850 from Lord's Bradley $\mathscr{G}$ Co.'s Cincinnati Counterfeit Detector and Bank Note Reporter, and for October through December 1853; January, February, and July 1854; August 1855 through February 1856; September 1857; and April 1860 from Lord's Detector and Bank Note Reporter.

I have three observations for Cleveland: January, June, and September 1856 from the Cleveland Bank Note Reporter published by the bankers Pierce \& Co.

In all these sources, discounts and premiums are quoted for banks throughout the country in terms of notes of banks in the particular city where the banknote reporter was published. These quotes are not quotes for exchanges of banknotes for specie. When banks are redeeming their notes for specie, this difference is not important. However, as shown in Section 2, it makes a difference when banks have suspended specie payment on their notes. My focus here is the prices of notes of banks that are actually in business. Consequently, quotes for the notes of banks that are "closed," "winding up," or "broken" are not taken into account. After the quotes for such banks are eliminated, I have over 200,000 individual banknote price observations covering more than 2000 banks. 
Figure A1: Discounts on banknotes vs. distance
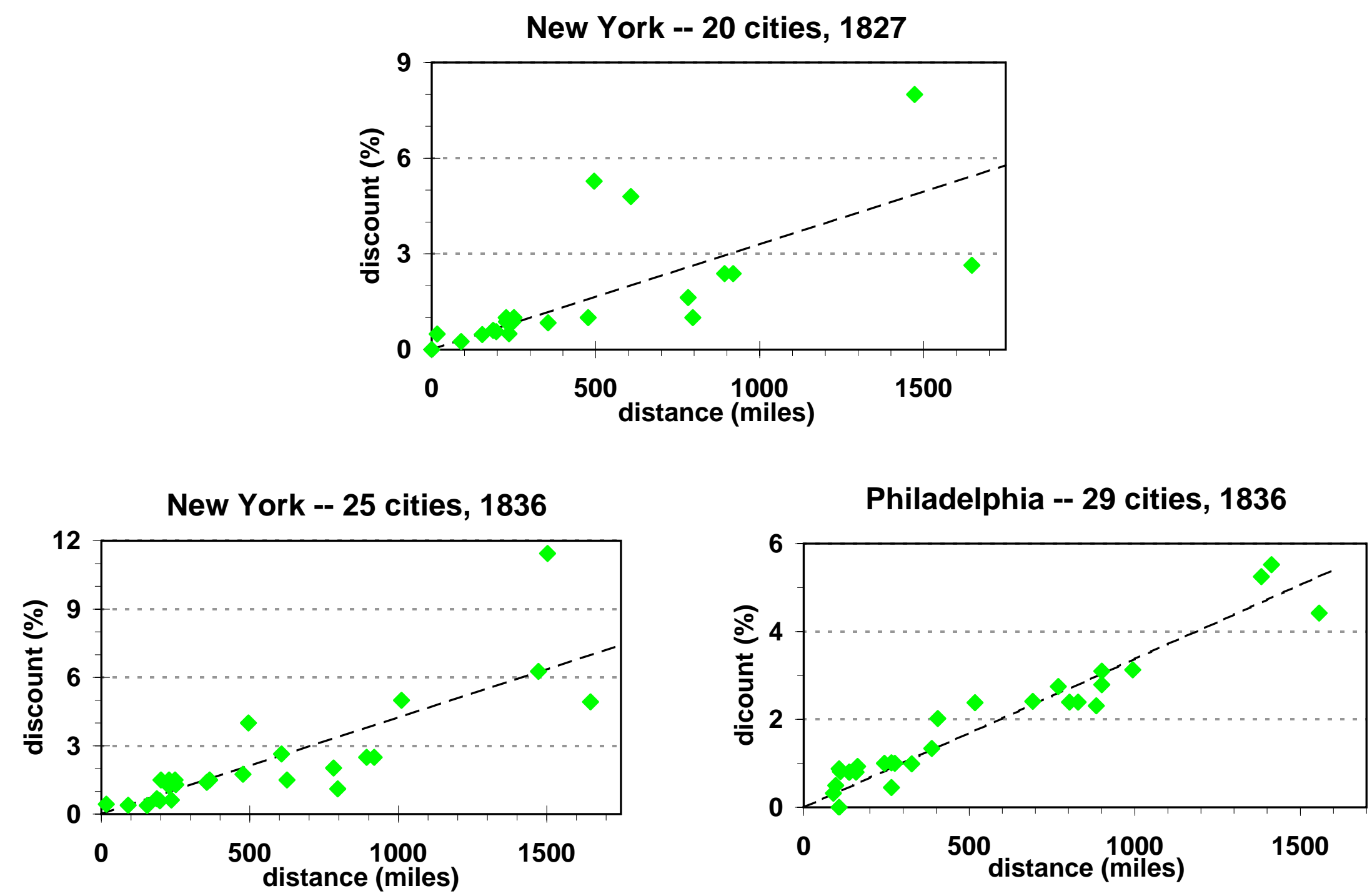